\title{
European Universities Experience in Distance Education
}

\author{
Dernova M. ${ }^{*}$ \\ Kremenchuk Mykhailo Ostrogradskyi National University, Kremenchuk, Ukraine
}

Received: $30.03 .2019 \quad$ Accepted: 12.04 .2019

\begin{abstract}
The article deals with distance education which has become one of the decisive trends in the development of higher education in European countries for the last decades. The spread of distance education is resulted by requirements for openness in higher education that have become a standard for universities and national educational systems. This caused objective changes in educational institutions and educational process. The article analyzes contemporary models of distance education in leading European open universities, such as Open University of Great Britain, Open University of Catalonia, Open University of the Netherlands, International Telematics University UNINETTUNO in Italy and University Aberta in Portugal. The article states that distance education gives a new meaning to student's autonomy due to its peculiarities, such as different means of communication for asynchronous study; individual teaching and learning; students personal responsibility for their successes, terms and pace of work; studying at the place of residence or work. Consequently, distance learning is not an extension of traditional learning opportunities but a new way of organizing knowledge delivery and student-teacher interaction. Summarizing the results of the analysis of the guidelines of the leading European open universities, it can be argued that their policy is aimed at: meeting students' future needs; developing skills of cooperative work; using effective up-to-date technology; giving the second chance for adults to get higher education; providing alternative paths to higher education; widening participation in higher education; experiencing student-centered approach; and promoting lifelong learning. As a result of the analysis, the features of distance learning that can be considered common to all these institutions have been determined. They are: openness and flexibility; networking and mobility; modularity of curriculum design; facilitative role of the teacher; specialized ICTs to support the interaction of educational process actors; virtual learning environment; student learning personalization through the creation of a personal learning environment.
\end{abstract}

Key words: open university, adult education, professional higher education, distance learning.

\section{Досвід європейських університетів в організації дистанційної освіти}

\author{
Дернова М. Г. \\ Кременчуцький національний університет імені Михайла Остроградського, Кременчук, Україна
}

\begin{abstract}
Анотація. Стаття присвячена проблемі дистанційної освіти, яка за останні десятиріччя стала однією 3 визначальних тенденцій розвитку системи вищої освіти у європейських країнах. Поширення дистанційної освіти найпомітніше проявляється в тому, що вимоги відкритості вищої освіти дедалі більше стають стандартом діяльності університетів і цілих національних освітніх систем. Про це свідчать об'єктивні зміни у навчальних закладах і навчальному процесі. У статті аналізуються сучасні моделі дистанційної освіти у провідних європейських відкритих університетах, таких як Відкритий університет Великобританії, Відкритий університет Каталонії, Відкритий університет Нідерландів, Міжнародний телематичний університет UNINETTUNO в Італії та Відкритий університет Португалії. У статті зазначається, що дистанційна освіта надає нового значення самостійності й автономії студента завдяки особливостям, які їй притаманні, а саме процес використання різних засобів зв'язку, що дозволяють навчатися у зручний для студента час; індивідуалізація навчання; особиста відповідальність студент за свої успіхи, термін і темп роботи; навчання за місцем проживання, роботи студента. Отже, дистанційне навчання являє собою не стільки розширення можливостей традиційного навчання, скільки новий спосіб організації трансляції знань і взаємодії суб'єктів навчального процесу. Узагальнення результатів аналізу керівних принципів провідних європейських відкритих університетів, дозволяє стверджувати, що їх політика спрямована на: відповідність майбутнім потребам
\end{abstract}

\footnotetext{
Corresponding Author: Dernova Maiia. Tel. +38(067)951-69-90. E-mail: maya.dernova@ukr.net. Kremenchuk Mykhailo Ostrogradskiy National University, Pershotravneva Str, 20, Kremenchuk, Ukraine, 39601.

Відповідальний автор: Дернова Майя Григорівна. Tel. +38(067)951-69-90. E-mail: maya.dernova@ukr.net. Кременчуцький національний університет імені Михайла Остроградського, вул. Першотравнева, 20, Кременчук, Україна, 39601.
} 
студентів; розвиток умінь спільної роботи; технологічність, що сприяє підвищенню ефективності роботи суб'єктів взаємодії; надання дорослим другого шансу отримати вищу освіту; забезпечення альтернативних шляхів до вищої освіти; розширення участі у вищій освіті; студентоцентризм у навчанні; сприяння навчанню впродовж життя. У результаті проведеного аналізу визначено особливості дистанційного навчання, які можна вважати загальними для усіх зазначених закладів. Зокрема: відкритість та гнучкість; мережевість та мобільність; модульність побудови навчальних програм; фасилітативна роль викладача; використання спеціалізованих IКT для підтримки взаємодії суб'єктів освітнього процесу; створення єдиного віртуального навчального середовища; персоналізація навчання студентів за допомогою створення особистого навчального середовища.

Ключові слова: відкритий університет, освіта дорослих, вища професійна освіта, дистанційне навчання

\title{
Опыт европейских университетов в организации дистанционного образования
}

\author{
Дернова М. Г. \\ Кременчугский национальный университет имени Михаила Остроградского, Кременчуг, Украина
}

\begin{abstract}
Аннотация. Статья посвящена проблеме дистанционного образования, которое за последние десятилетия стало одной из определяющих тенденций развития системы высшего образования в европейских странах. Распространение дистанционного образования заметно проявляется в том, что требования открытости высшего образования все больше становятся стандартом деятельности университетов и целых национальных образовательных систем. Об этом свидетельствуют объективные изменения в учебных заведениях и организации учебного процесса. В статье анализируются современные модели дистанционного образования в ведущих европейских открытых университетах, таких как Открытый университет Великобритании, Открытый университет Каталонии, Открытый университет Нидерландов, Международный телематический университет UNINETTUNO в Италии и открытый университет Португалии. В статье отмечается, что дистанционное образование придает новое значение самостоятельности и автономии студента благодаря особенностям, которые ему присущи, а именно использование различных средств связи, позволяющих учиться в удобное для студента время; индивидуализация обучения; личная ответственность студента за свои успехи, срок и темп работы; обучение по месту жительства, работы студента. Дистанционное обучение представляет собой не столько расширение возможностей традиционного обучения, сколько новый способ организации трансляции знаний и взаимодействия субъектов учебного процесса. Обобщение результатов анализа руководящих принципов ведущих европейских открытых университетов позволяет утверждать, что их политика направлена на: соответствие будущим потребностям студентов; развитие умений совместной работы; технологичность, что способствует повышению эфффективности работы субъектов взаимодействия; предоставление взрослым второго шанса получить высшее образование; обеспечение альтернативных путей к высшему образованию; расширение участия в высшем образовании; студентоцентризм в обучении; содействие обучению на протяжении жизни. В результате проведенного анализа определены особенности дистанционного обучения, которые можно считать общими для всех указанных учреждений. В частности: открытость и гибкость; сетевая структура и мобильность; модульность построения учебных программ; фасилитативная роль преподавателя; использование специализированных ИКТ для поддержания взаимодействия субъектов образовательного процесса; создание единой виртуальной учебной среды; персонализация обучения студентов посредством создания личного учебной среды.
\end{abstract}

Ключевые слова: открытый университет, образование взрослых, высшее профрессиональное образование, дистанционное обучение.

\section{Bcmyn}

Сучасні тенденції загальносвітового розвитку пов'язані зі становленням демократичного, відкритого суспільства, формування якого спричиняє перетворення соціального простору, модернізацію соціальних інститутів. Тому у сфері освіти ідеї відкритості знаходять втілення в дистанційних моделях освіти, які розвиваються під впливом змін, що відбуваються в суспільстві, і завдяки демократизму та високому динамізму повною мірою відповідають сучасним соціальним реаліям. Розвиток дистанційної освіти (ДО) за останні десятиріччя є однією з визначальних тенденцій розвитку системи вищої освіти у європейських країнах, де в рамках Болонського процесу формується загальноєвропейська інтегральна система вищої освіти. Поширення дистанційної освіти, напевно, найпомітніше проявляється в тому, що вимоги відкритості вищої освіти дедалі більше стають стандартом діяльності університетів і цілих національних освітніх систем. Про це свідчать об'єктивні зміни у навчальних закладах і організації 
навчального процесу. Важливим і перспективним напрямком розвитку сучасної системи вищої освіти в європейських країнах є широке впровадження ДО на основі використання сучасних інформаційних і телекомунікаційних технологій. Це підтверджується тим фрактом, що наразі у європейській дистанційній вищій освіті нараховується близько 3 мільйонів студентів [16]. 3 них близько двох третин навчається в університетах дистанційного навчання (single-mode institutions). Решта - у вищих навчальних закладах, які пропонують дистанційну освіту поряд з традиційною (dual-mode institutions).

Mета роботи: проаналізувати сучасні моделі дистанційної освіти у провідних європейських відкритих університетах та визначити їх загальні особливості.

\section{II Матеріал і методи дослідження}

Увагу нашого дослідження привертають спеціалізовані університети ДО (відкриті та університети ДО) у країнах Євросоюзу, оскільки саме вони реалізують найповніше модель ДО. Університетами ДО вважають ті, єдиною місією яких є ДО, а їх навчальні курси, інструкції, оцінювання та інші навчальні процеси розроблені спеціально для студентів, які навчаються на відстані [11].

У виборі європейських університетів для подальшого аналізу моделей ми спирались на рейтинг Європейської асоціації університетів дистанційного навчання (European Association of Distance Teaching Universities). Наразі найбільшими університетами ДО, за даними асоціації [3], вважаються такі:

1) відкритий університет Великої Британії (200000 студентів);

2) національний університет дистанційної освіти Іспанії (205000 студентів);

3) університет дистанційної освіти в Хагені,Німеччина (76689 студентів);

4) відкритий університет Каталонії (49672 студента);

5) відкритий університет Греції (37653 студента);

6) відкритий університет Нідерландів (25938 студентів);

7) міжнародний телематичний університет UNINETTUNO, Італія (10000 студентів);

8) університет Аберта, Португалія (10000 студентів);

9) відкритий університет Кіпру (4700 студенів).

Водночас кількість членів ЄАДУ, що утворюють асоціації чи консорціуми традиційних університетів, фрактично перевищує кількість відкритих та університетів ДО в Європі. Це свідчить про те, що дворежимні університети наразі стали правилом, а не винятком. У звіті Європейської асоціації університетів, відзначено, що трохи більше половини (53\%) усіх європейських університетів пропонують ДО. Проте для окремих країн, наприклад, скандинавських, цей відсоток набагато вищий, оскільки майже всі університети мають ДО [18]. Аналіз документів ЮНЕСКО щодо ДО свідчить, що середній вік студентів, які навчаються дистанційно в університетах Європи, становить від 25 до 44 років; більшість 3 них (60 \%) мають постійне місце роботи, а також ступінь бакалавра $(57,04 \%)$. Переважна кількість їх умотивовані можливістю кар'єрного росту та підвищенням кваліфікації (62 \%), інші задоволенням від навчання (28 \%), деякі - запобіганням безробіття (8 \%) [12]. Популярність ДО серед дорослого населення зумовлена тим, що воно дозволяє реалізувати різні потреби. Наприклад, більшість студентів повертаються до вищої освіти, або вперше вступають до університету після тривалого періоду роботи або академічної відпустки. Для інших ДО означає другий шанс після того, як вони втратили можливість здобути освіту раніше у своєму житті. Ще однією групою студентів ДО є пенсіонери, які навчаються для самореалізації або для того, щоб залишатися активними. Існує низка чинників, що стимулюють студентів до участі у ДО:: необмеженість у часі, відстані та гнучкість; мова навчання; подолання проблем доступу - таких як обмежені можливості, проблеми здоров'я, віддалені райони. По-третє, ДО надає ефективні структури підтримки: навчальні матеріали; можливість взаємодії 3 викладачами та іншими студентами; академічна підтримка; адміністративна/організаційна підтримка; моральна та психологічна підтримка та консультування [15https://idealprojectblog.files.wordpress.com/2013/11/ideal-report-2-final.pdf].

\section{III Результати}

Аналіз освітніх моделей вищезазначених університетів ДО свідчить, що кожен університет має власні особливості щодо проектування освітнього процесу, деякі з них функціонують за класичною 
моделлю дистанційного відкритого навчання.

Втім позицію лідера у сфері відкритого та дистанційного навчання майже сорок років займає Відкритий університет Великобританії. Його освітня модель називається «підтримуваним відкритим навчанням» (supported open learning). Вона має наступні особливості: якісні навчальні матеріали; індивідуальну академічну підтримку кожного студента; ефективне адміністрування, логістику та навчальну аналітику; навчання, засноване на дослідженні [19]. Модель підтримуваного відкритого навчання ґрунтується на соціально-конструктивістському підході у педагогіці [7].

Усі курси (тобто модулі) розробляються централізовано командами, які зазвичай складаються з академічних співробітників, медіа-дизайнерів, редакторів та адміністративного персоналу. Курс може містити різні компоненти: такі, що доставляються через відкрите джерело віртуального навчального середовища на основі Moodle; веб інструментарій (аудіовізуальні, текстові, інтерактивні додатки); диски (DVD-ROM); паперові носії інформації (книги, навчальні посібники, академічні статті, додаткові матеріали), але здебільшого за допомогою електронної книги (e-books) та інтерактивної електронної книги (i-books). Як правило, кожен студент отримує пакет матеріалів та інструкцій поштою, здебільшого ці матеріали доступні та завантажуються з Інтернету через персональні комп'ютери, ноутбуки та мобільні пристрої. Студенти зараховуються до групи і навчаються за допомогою тьютора. Тьюторська мережа є важливим елементом навчальної моделі ВУ.

Слід зазначити, що педагогічна модель ВУ, перш за все, враховує особливості дорослих студентів. Оскільки більшість з них працюють повний робочий день і дуже обмежені в часі, переважає асинхронна модель навчання. По-друге, більшість студентів не мають навичок навчання, які притаманні звичайним випускникам шкіл, тому вони потребують підтримки педагогів і добре розроблених навчальних матеріалів. Крім того, враховано унікальні характеристики і доступність кожного середовища, ретельно розроблена медіа-суміш для спільного навчання за допомогою технологій інтерактивного навчання та спілкування між учасниками навчального процесу.

3 метою налагодження безперервного шляху від вступу до закінчення навчання у 2014 році у ВУВ була упроваджена нова схема підтримки студентів «Модель інтегрованого навчання та підтримки студентів» (Model for Integrated Learning and Learner Support, MILLS). За цією моделлю команди підтримки складаються з наукових працівників та допоміжного персоналу, які надають студентам індивідуальну допомогу щодо змісту і методів навчання. Використовуючи аналітичні дані навчання та тісно співпрацюючи з тьюторами, команди підтримки забезпечують активне мотивування студентів завдяки своєчасному втручанню [14].

Іншою особливістю моделі навчання у ВУВ $є$ платфрорма OpenLearn, завдяки якій навчальні матеріали курсів стали відкритими (Open Educational Resources, OER). Високоякісні мультимедійні матеріали дають можливість організувати багато видів робіт (наприклад, питання для самооцінки та повторення). Вони значною мірою самодостатні. Крім того, розширене середовище Moodle, яке підтримує OpenLearn, надає безкоштовні доступні онлайн-форуми [17; 2].

OpenLearn складається 3 двох сайтів: Learning Space, що призначений для студентів та OpenLearn Works (LabSpace), що спрямований на педагогів, де вони можуть завантажувати навчальний матеріал, доопрацьовувати його та вносити правки [10]. Кожен юніт матеріалу забезпечує від 4 до 30 годин навчального часу і має відповідний рівень навчання [9].

Віртуальне середовище OpenLearn не має перешкод для доступу. Однак відправною точкою є зміст, розроблений для задоволення потреб конкретної групи студентів. Ґрунтуючись на принципах підтримуючого навчання, компоненти навчального матеріалу, підтримка та оцінка тьютора інтегровані у спільний навчальний досвід, що робить навчання ефективним і приємним. OpenLearn також об'єднує відео та аудио матеріали, доступні через інші канали ВУ, зокрема iTunesU, YouTube та AudioBoo.

OpenEducation дозволяє користувачам завантажувати, модифікувати, перекладати та пристосовувати навчальні матеріали до своєї культури, щоб підвищити їх корисність; дають можливість працювати разом, спільно модифікувати, розробляти та випробовувати похідні матеріали, що створює цикл швидкого безперервного їх удосконалення.

Завдяки віртуальному навчальному середовищу на основі Мoodle студентам пропонується понад 600 структурних мультимедійних навчальних підрозділів, які підтримуються навчальними та комунікаційними інструментами. Особисті профрілі, навчальні журнали та рейтингова структура надають 
студентам можливість стати самостійними видавцями та рецензентами. Публікуючи свою роботу в інтернеті, вони діляться своїми думками з іншими відвідувачами веб-сайту. Програмне забезпечення для репрезентації знань дозволяє студентам візуально представляти ресурси та зв'язки між ними, аргументувати та спільно обговорювати обрані проблеми.

Іншою особливістю моделі дистанційного навчання у ВУ $€$ відкрита навчальна платформа FutureLearn для відкритих онлайн-курсів (MOOCs).3 травня 2016 року студенти, які пройшли відповідний онлайн-курс, можуть заробити кредити, що зараховуються у формальному університетському навчанні для отримання ступеня.

У відкритому університеті Каталонії (ВУК) в Іспанії освітня модель орієнтована на колективну участь та формування знань, а також охоплює навчальний, соціальний та професійний досвід студентів. Вона поєднує індивідуальну та колективну роботу студентів, збагачуючи навчальний процес студента знаннями, думками та досвідом одногрупників, а також розвиваючи навички роботи у команді.

Студента завжди підтримує команда викладацького персоналу, основними функціями якого $є$ розробка, керівництво, керування та оцінка навчального процесу. В університеті викладацький персонал поділяється на професорів, тьюторів та викладачів курсу, які працюють спільно для забезпечення якості навчального процесу. Професор розробляє курс, забезпечує його якість і координує тьюторів курсу. Викладач курсу проводить та оцінює процес навчання у рамках певного курсу. Тьютор консультує студента щодо вибору індивідуального навчального курсу у ВУК.

Віртуальний кампус ВУК $є$ середовищем, де всі ці елементи поєднуються і стають взаємопов'язаними. Життя всієї університетської спільноти, до складу якої входять студенти, викладачі, дослідники, адміністративні працівники, відбувається у віртуальному кампусі. Через кампус студент має доступ до віртуальних класів, які $€$ навчальним центром, де можна знайти викладачів, одногрупників, різні види діяльності, зміст та інструменти навчання.

\section{Елементи моделі:}

1. Навчальна підтримка. Це поєднання дій викладацького складу та тьюторів для моніторингу діяльності і результатів навчання студентів та наданням допомоги у прийнятті рішень, плануванні навчального процесу, завершенні діяльності та оцінюванні. Крім того, завдяки цій підтримці студенти отримують індивідуальну допомогу, користуються постійним керівництвом упродовж своєї академічної кар'єри та встановлюють тісні зв'язки з громадою.

2. Мережева спільнота. Це спільна комунікативна діяльність студентів та викладацького складу, яка полегшує спільне фрормування знань студентами та викладачами.

3.Навчальніресурси. До них відносяться навчальні матеріали, середовища та інструменти, необхідні для завершення навчальної діяльності, та їх відповідна оцінка.

Модель можна вважати гнучкою, оскільки вона дозволяє використовувати широке коло навчальних заходів, щоб охопити певні компетенції, область знань та рівень освітньої спеціалізації, у якій задіяний студент. Для реалізації навчальної мети ВУК використовує найсучасніші інформаційнокомунікативні технології та інструменти, щоб допомогти студентам навчатися, зокрема:

- соціальні інструменти, що полегшують взаємодію та обмін знаннями (блоги, вікі, мікроблоги, соціальні закладки тощо);

- мультимедійні ресурси, які забезпечують інтерактивний та цікавий зміст;

- інтерактивні та багатоформатні матеріали, такі як відеоролики, гіпертекстові посилання, аудіокниги та відео кліпи;

- розширені синхронні та асинхронні системи зв'язку, що забезпечують плавне та чітке спілкування у будь-якій ситуації (відеочати, форуми, відеоблоги тощо); ситуації;

- іммерсивні середовища, що дозволяють взаємодіяти з людьми та об'єктами, імітуючи реальні

- мобільні пристрої, які надають легкий доступ до змісту та навчання, що дозволяє студентам навчатися будь-коли та будь-де.

Також заслуговує на увагу освітня модель Відкритого університету Нідерландів (ВУН), яка ґрунтується на концепції віртуального навчального середовища (ВНС), соціальних мереж та особистого навчального середовища $(\mathrm{OHC})$,що представляють собою формальне, соціальне і персональне навчання [5], або, іншими словами, фрормальне, неформальне та інформальне навчання. 
Для розробки інноваційної інтегрованої системи он-лайн навчання у ВУН була прийнята концепція навчальних мереж [8], де навчальна мережа визначається як спільнота, що технологічно підтримує людей, які допомагають один одному краще зрозуміти і керувати певнимиподіями та поняттямиу роботі чи житті. Як результат, участь студентів у навчальних мережахстимулює їх професійний розвиток, сприяв кращому розумінню подій,розвитку кар'єри та забезпечує можливість працевлаштування.

Модель навчання ВУН сприяє гнучкості та індивідуалізації навчання в інтернеті [4]; підтримує високий рівень деталізації у наданні доступу до курсів та свободи студента у виборі шляхів навчання. Бакалаврські та магістерські програми мають певну кількість «вільних» кредитів, які студенти можуть використовувати за власним бажанням.

Освітня модель ВУН має наступні характеристики: активне он-лайн навчання;

- акредитація попереднього навчання;

- фіксований навчальний рік (вересень-серпень) - 5 навчальних періодів по10 тижнів;

- студентські спільноти (групи);

- віртуальне навчальне середовище;

- швидкість просування у навчанні $€$ частиною структури курсу, за яку несуть спільну відповідальністьстуденти, викладач і група;

- веб-центр з електронними матеріалами;

- вбудована дидактична підтримка, тьютор курса, ментор програми;

- індивідуальні та групові навчальні заходи;

- менше попередньо розроблених матеріалів, доставка навчальних матеріалів через інтернет, немає пакету навчальних матеріалів для курсу. Студенти замовляють потрібні книги в книжкових магазинах. Кожен курс навчання можна коригувати за необхідності. Викладач несе відповідальність за розробку та викладання курсів;

- організований зворотний зв'язок щодо виявлення динаміки, виконання усних та письмових завдань, менше завдань з множинним вибором [20].

Водночас основним навчальним інструментом Міжнародного телематичного університету UNINETTUNO в Італії $є$ навчальне інтернет-середовище, що дозволяє впровадити нову психологопедагогічну модель, що характеризується: центральною роллю студента у навчанні; конструюванням знань, а не їх трансляцією; інтеграцією теорії і практики; активним та спільним навчанням.

Ця освітня модель характеризується високим ступенем гнучкості для студента, оскільки студент може будувати свій власний шлях навчання, залежно від його освітніх потреб та рівня майстерності. Освітнє середовище розроблене таким чином, що не обмежується заздалегідь жорстко встановленими курсами, але пропонує динамічний зміст, який може бути збагачений інтернет-ресурсами. Фактично, у Міжнародному телематичному університеті UNINETTUNO студент знаходиться у центрі навчального процесу, однак він скеровується професором або тьютором, який зобов'язаний забезпечити інструменти, необхідні для полегшення процесу навчання та спілкування в мережі у синхронному та асинхронному режимі [6].

Організаційною структурою UNINETTUNO $€$ «мережева структура»: координаційний центр, технологічні центри та виробничі центри, розташовані в Італії та інших країнах, з'єднані між собою комп'ютерними мережами, а також через супутникові антени. Наразі UNINETTUNO може спиратися на існуючі в Італії 31 технологічний та 9 методичних центрів, які створено в університетських містечках та центрах професійної підготовки у межах проекту в 11 країнах європейської частини Середземномор'я. Технологічний центр - це освітня структура, оснащена новітніми інформаційно-комунікаційними технологіями (IКT), яка надає студентам технологічні можливості стежити за курсами дистанційного навчання, брати участь в освітньому процесі через відео конференцію та складати іспити; вона виконує функції координації та нагляду за освітньою та дослідницькою діяльністю та забезпечує фізичне місце зустрічі та взаємодії студентів, викладачів та тьюторів. Методичний центр - це структура, що забезпечена усім обладнанням, необхідним для створення мультимедійних навчальних матеріалів в інтернеті, доступних на освітньому порталі, який $є$ першим в світі дистанційним порталом навчання, який працює на чотирьох мовах (арабській, англійській, французькій та італійській).

Процес учіння і навчання відбувається через інтернет. На університетському порталі www.uninettunouniversity.net $€$ освітній кіберпростір, де учіння та навчання відбуваються на п'яти мовах: 
італійській, арабській, англійській, французькій та грецькій. Освітнє інтернет-середовище транслюється на комп'ютер студента: заняття, мультимедійні продукти, бази даних, вправи, системи оцінювання та самооцінки, онлайн-навчання, форуми, чати та тематичні вікі.

Педагогічний колектив, який здійснює освітні та дослідницькі функції відповідно до моделей дистанційного навчання через комп'ютерні та супутникові мережі (інтернет, телебачення та системи відеоконференцій),складається з:

- профільного професора (Area Professor), який координує навчальну діяльність для кожної предметної галузі знань;

- професор - автор змісту (Professor author of the contents), який записує відеолекції та розробляє зміст і матеріали, що будуть включені до навчального середовища освітнього порталу;

- $\quad$ тьютор перевіряє успішність навчання студентів.

В психолого-педагогічній моделі UNINETTUNO відеолекції грають важливу роль; їх записують професори з кращих університетів Італії та світу; потім вони оцифровуються і публікуються, що дозволяє використовувати гіпермедіа. Студент може стежити за відеосесіями відповідно до лінійної послідовності або контролювати навчальний процес через паузу, повертаючись назад або рухаючись по різним етапам заняття на свій розсуд. Він також може використовувати інструменти, доступні на порталі UNINETTUNO, зокрема за допомогою інтерфейсу, розробленого UNINETTUNO, студент може подорожувати по відеолекціям, переходячи від однієї до іншої, за допомогою меню.

Крім того, у певні моменти часу на передній план виходить так звана закладка, яка більш подає поглиблений навчальний матеріал, пов'язаний з тим, про що говорить професор в конкретний момент відеолекції. Таким чином, процес навчання стає гіпермедійним: студент може отримати доступ до більш глибокого змісту у режимі реального часу за допомогою гіпермедіайних закладок, структурованих професорами та дослідниками, які дозволяють студенту безпосередньо звернутися до книг і статей, тобто текстів, лекційних записів, ессе, які відібрані й надані професорами та дослідниками, CD-Roms, мультимедійні матеріали, фотогалереї, фільми, пов'язані з відеолекціями; бібліографічні посилання та окремі списки веб-сайтів, збірники посилань на зовнішні матеріали, затверджені професорами та тьюторами кожного окремого курсу; вправи і віртуальні лабораторії.

Завдяки вправам і віртуальним лабораторіям студенти мають у своєму розпорядженні матеріали, які дозволять їм реалізувати на практиці знання, отримані під час вивчення навчальних матеріалів. Мета полягає в тому, щоб створити потужну синергію у віртуальній лабораторії, щоб теоретичне навчання та практичне розв'язання проблем співіснували у правильному співвідношенні та повністю інтегрувалися: студент може вдосконалювати свій досвід у навчальному середовищі, а абстрактні принципи, описані викладачем, стають мотивуючим й операційними, тобто відбувається інтеріоризація завдяки проблемним методам навчання.

Слід звернути увагу на той факт, що у 2008 році університет Аберта став еталонним європейським університетом у сфрері вдосконалення електронного навчання та онлайн-навчання шляхом визнання його віртуальної педагогічної моделі.

Модель університету Аберта базується на чотирьох основних принципах: студентоцентроване навчання, гнучкість, взаємодія та цифрова інклюзія. Ці принципи є керівними в організації навчання, плануванні та управлінні діяльністю студентів, розробці навчальних матеріалів та оцінюванні компетенцій [13].

В основі моделі лежить дорослий студент як активний індивідуум, конструктор власних знань, що займається та здійснює навчальний процес у навчальній спільноті. Згідно з цією умовою, навчальні ситуації розробляються з огляду на студента та процес навчання, які повинні призвести до опанування та розвитку трансверсальних компетенцій, необхідних для суспільства знань, а також для набуття специфічних компетенцій у межах обраної студентом спеціалізації. Навчання відбувається як за допомогою самостійних стратегій навчання, так і шляхом діалогу та взаємодії з одногрупниками, використовуючи колективні стратегії навчання. Самостійне навчання здійснюється індивідуально 3 використанням навчальних матеріалів, бібліографії та вказівок, наданих викладачем. Колективне навчання - це спільна робота з іншими студентами, обмін досвідом та перспективами, загальні цілі та робочі процеси, які обговорюються у групі. Створення та організація груп студентів забезпечує соціальний контекст навчання, оскільки ця стратегія запобігає появі почуттів ізоляції та демотивації, 
характерних для традиційних моделей дистанційної освіти. Крім того, командна робота готує студентів працювати в сучасних організаціях, де завдання здебільшого взаємозалежні, а обмін інформацією та знаннями став ключовим чинником разом із узгодженими професійними діями. Студент активно бере участь в управлінні темпами та часом здійснення діяльності, моніторингу навчальних досягнень, у встановленні цілей навчання та створенні навчальних спільнот, які моделюються самими студентами. Ці методи навчання дозволяють студентам розвивати автономію та творчість, набувати здатність стежити за власними результатами та планувати свою освіту, готувати себе до навчання упродовж життя.

Замість того, щоб сприяти передачі знань та оцінці кількості інформації, яку студент зміг зберегти, викладач виконує функції фасилітатора освітнього процесу, допомагаючи студентам розвивати метакогнітивні навички, та модератора, організовуючи співпрацю та стимулюючи взаємодію у навчальній спільноті. Поряд з фундаментальною важливістю взаємодії в навчальному процесі, викладач повинен опанувати знаннями та навичками командної роботи, надавати доступ до різноманітних навчальних ресурсів та сприяти різноманітним навчальним ресурсам, а також організовувати заходи, що сприяють обміну досвідом, знаннями у межах групи.

Другий принцип, який підтримує освітню діяльність в університеті Аберта, - це гнучкість, яка розглядається як змінна, що інтерпретує оригінальну матрицю дистанційної освіти та просріль потенціальних студентів, які здебільшого $є$ дорослими з професійними, сімейними та громадськими обов'язками, активні громадяни суспільства. Незважаючи на те, що сучасні технології забезпечують засоби синхронного зв'язку, модель університета Аберта заснована переважно на асинхронному режимі навчальної взаємодії. Наразі акцент робиться на дискусійних форумах та інших асинхронних інструментах, що містить у Web 2.0. 3 цієї точки зору, процес учіння і навчання $є$ безперервним і незалежно від часу та простору, у якому знаходяться викладачі та студенти. Це розглядається як фундаментальний аспект гнучкості (як для студентів, так і для викладачів), оскільки дозволяє студентам навчатися на відстані та поєднувати їх професійне та сімейне життя з навчанням в університеті. Асинхронний режим взаємодії суб'єктів навчального процесу полегшує студентам управління часом доступу до інтернету, індивідуальним дослідженням, вивченням предметів та взаємодією з викладачем та іншими студентами. Можливість брати участь у дискусіях та обговореннях без фіксованого графріку значно збільшує гнучкість щодо управління часом. 3 іншого боку, асинхронні інструменти демократизували дискурс, дозволяючи кожному брати участь у обговоренні, уникаючи ситуацій, коли може бути зменшення кількості учасників. Це дозволяє розглянути різні думки, покращує обмін інформацією, а, отже, сприяє уникненню інтелектуальної та афективної ізоляції, що забезпечує вищий рівень рефрлексії. Щоб підвищити гнучкість, для всіх навчальних програм, які є частиною формальних навчальних програм у всіх навчальних циклах, упроваджено семестровий режим навчання. Семестровий режим дозволяє покращити управління роботою студентів, водночас дає можливість підтримувати їх активну участь.

Серед наріжних камінів дистанційної моделі навчання в Університеті Аберта - цифрова інклюзія, що спрямована на забезпечення доступу до дистанційної освіти дорослим, які хочуть навчатися у вищому навчальному закладі, але ще не набули навичок користування інформаційними та комунікаційними технологіями.

Сучасні технічнологічні досягнення, соціальні відносини, світ робочої сили, обмін товарами та послугами, які $є$ важливими для повсякденного життя, дедалі більше залежать від віртуальних мереж та доступу до інформаційно-комунікаційних систем. Тому інформаційне виключення (info-exclusion) $€$ синонімом соціального відторгнення та маргінальності, і цей фракт освітні установи не ігнорують для збереження своєї соціальної цінності. Проте технології розвиваються так швидко, що багатьом освітнім закладам важко вирішити цю проблему. Отже, важливо, щоб формальна дистанційна освіта дорослих сприяла зменшенню розриву між виключеними та включеними до інформації. У цьому контексті університет Аберта сприяє розбудові суспільства знань, яке охоплює використання IКТ у сфері освіти та підготовки дорослих відповідно до рекомендацій Лісабонської стратегії щодо політики в галузі освіти.

Серед особливостей навчальної моделі в університеті Аберта $€$ план формативних видів діяльності (Formative Activities Plan), який складається викладачем, щоб надати студентам можливість самим контролювати свою роботу та набуття проміжних цілей і компетенцій упродовж навчального 
циклу. Типологія цих видів діяльності варіюється залежно від наукової галузі та компетенцій, які необхідно набути, і супроводжується індикаторами для самостійного оцінювання діяльність студентів. Таким чином, студенти можуть контролювати своє навчання, порівнюючи його ефективність з тією, яку очікує викладач. Проте це не стосується діяльності, призначеної для тренінгу студентів у відповідь на екзаменаційні запитання. Метою плану вважається допомога студентам визначити сильні та слабкі сторони їх навчання для подальшого обговорення зі своїми одногрупниками та, за необхідності, 3 викладачем. Деякі навчальні дисципліни можуть передбачати специфічні види діяльності, але в цілому заходи, що пропонуються студентам, можуть приймати різноманітні фоормати, такі як вирішення проблем, підготовка концептуальних карт та написання звіту, коментарів або резюме, відповіді на вибіркові тести з автоматичною корекцією. Іншою особливістю цієї моделі ДО університету Аберта $є$ навчальна картка студента (САР), призначена для оцінки студентом власного навчального прогресу. Це персоналізований пристрій, який об'єднує результати навчальної діяльності студента. Філософія навчальної карти спирається на концепцію електронного фоліо як інструмента для безперервного оцінювання. Концепція базується на оригінальній ідеї фоліо (аркуш паперу), адаптованого до віртуального (електронного) режиму. Таким чином, електронний фоліо (е-фоліо) $є$ коротким цифрровим документом, розробленим студентом та опублікованим в інтернеті для візуалізації й демонстрації набутих компетенцій. Очікується, що студенти вироблятимуть два-три е-фроліо в межах навчального модуля відповідно до графріка, визначеного викладачем.

Педагог визначає тип роботи, що вимагається від студентів, та формат е-фоліо, який буде виготовлений, відповідно до особливостей галузі знань, що охоплює навчальний модуль, та компетенцій, які оцінюються. Е-фоліо може бути доповнений п-фоліо, що виконано у паперовому форматі. Воно може складатися з документа, розробленого студентом, у відповідності з низкою питань, визначених викладачем, або приймати інші форми, такі як подання проекту або доповіді, відповідно до характеру компетенцій, яких студент має набути. Таким чином, використовуючи навчальну карту, студенти поступово інвестують у процес поточного оцінювання, фіксуючи отримані оцінки. Крім того, ця система дозволяє оцінювати компетенції упродовж семестру, а особливо ті, що важко оцінити, використовуючи традиційні інструменти, такі як письмовий випускний іспит. Студенти накопичують ебали за розроблене е-фроліо. Остаточний бал у навчальному модулі - сума балів, отриманих за е-фоліо i, якщо це було вимогою викладача, п-фоліо. Якщо за певний рік студент не може отримати оцінку, яка б дозволила йому успішно закінчити навчальний модуль, частина накопиченого кредиту може перейти до іншого навчального року, коли вони зараховуються до того ж навчального закладу.

Узагальнюючи результати аналізу керівних принципів ведучих європейських університетів ДО, можна сказати, що їх політика спрямована на:

- відповідність майбутнім потребам студентів формування їх соціальної відповідальності через професійне спрямування навчання, здобуття ними відповідних навичок і вмінь для активної участі в житті інформаційного суспільства;

- розвиток умінь спільної роботи через створення можливостей для зміцнення відносин між спільнотами університету (викладацький штат, студенти, роботодавці) та іншими 3ВО, а також співпрацю щодо розробки навчальних матеріалів;

- технологічність, що сприяє підвищенню ефективності роботи суб'єктів взаємодії;

- надання дорослим другого шансу отримати вищу освіту та забезпечити альтернативні шляхи до вищої освіти;

- розширення участі, відкритості й доступу для широких верств населення, що передбачає впровадження інноваційних методів навчання, які допомагають організувати навчання у різноманітних контекстах, а також задовольнити потреби різних груп студентів;

- студентоцентризм у навчанні, що передбачає підтримку студентів упродовж навчання, розвиток їх самокерованості й автономії, а також визнання попереднього досвіду;

- сприяння навчанню впродовж життя, надаючи кожному можливість навчатися без будь-яких обмежень, таких як вік, місце чи час $[1 ; 5]$. 


\section{IV Обговорення}

Прагнучи задовольнити нові та постійно змінювані вимоги до вищої освіти, ДО розглядається як модель освіти, яка слугує відповідним замінником традиційної освіти, у якій переважають F2F методи. У студента ДО є більша свобода доступу, а отже, і ширший спектр можливостей для навчання та підвищення кваліфікації. ДО долає не тільки перешкоди географічного відстаню, а й культурні та соціальні бар'єри, брак освітньої інфрраструктури. Оскільки багато дорослих не можуть дозволити собі залишити роботу задля навчання, важливою характеристикою ДО вважається саме можливість поєднання навчання з роботою. Для роботодавців ДО пропонує можливість організації навчання та профресійного розвитку на робочому місці, що часто $€$ більш гнучким і економить витрати на проїзд, проживання тощо. Ці переваги для студентів та роботодавців також $є$ важливими для ДО, оскільки їі метою $€$ розширення доступу до навчання; забезпечення більших можливостей для оновлення, перепідготовки та особистого зростання; підвищення економічної ефективності освітніх ресурсів; підтримка якості та різноманітності існуючих освітніх структур; збалансування нерівності між віковими групами; розширення географрічного доступу до освіти; надання освіти широкій аудиторії; забезпечення швидкого та ефрективного навчання для ключових цільових груп; розширення можливостей для освіти в нових і міждисциплінарних тематичних галузях; поєднання освіти з роботою та сімейним життям; розвиток різноманітних компетенцій шляхом періодичної та безперервної освіти; посилення міжнародного виміру навчального досвіду; підвищення якості існуючих освітніх послуг [11].

Між іншим, ДО надає нового значення самостійності й незалежності (автономії) дорослого завдяки особливостям, які їй притаманні, зокрема: процес навчання здійснюється за допомогою різних засобів зв'язку, що дозволяють навчатися у зручний для студента час; навчання індивідуалізоване; найбільш зручним місцем навчання є місце проживання, роботи; студент відповідає за свої успіхи й вільний у виборі строків і темпів роботи.

Отже, ДО являє собою не стільки розширення можливостей традиційної організації навчання, скільки новий спосіб трансляції знань, де навчання відбувається за індивідуальним навчальним планом, а студенти й викладачі здійснюють комунікацію у межах дистанційної освітньої системи.

\section{V Висновки}

Отже, спираючись на аналіз існуючих моделей ДО у провідних університетах країн Євросоюзу, визначимо особливості моделей ДО:

1. Відкритість та гнучкість. Студенти не відвідують регулярних занять, організованих за традиційною формою (лекції, семінари тощо), а працюють у зручний час, у зручному місці й у зручному темпі. Міжсуб'єктна взаємодія може здійснюватися в асинхронному та синхронному режимах. Для кожного студента розробляється індивідуальний навчальний план, який за рахунок індивідуальної диференціації навчальних модулів адаптується до базового рівня знань, спрямованості попередньої освіти, а також конкретних цілей навчання кожного студента.

2. Мережевість та мобільність, що надає можливість студентам навчатися за межами національних, галузевих та інституційних кордонів.

3. Модульність побудови навчальних програм. В основу програм покладений модульний принцип. Це дозволяє з переліку незалежних курсів-модулів формувати навчальну програму, яка відповідає індивідуальним потребам дорослих студентів. Програма може включати окремі навчальні модулі. Такий підхід дозволяє студенту пройти окремі модулі в інших закладах освіти або МООС.

4. Фасилітативна роль викладача. У дО функції, які виконує викладач змінюються: деякі відомі функції стають домінуючими (наприклад, координація навчально-пізнавального процесу, коригування курсу, який викладається, керівництво навчальними проектами, перевірка поточних знань тощо), і виникають нові (наприклад, консультування щодо розробки індивідуального навчального плану, управління групами підтримки студентів, допомога у професійному самовизначенні тощо).

5. Використання спеціалізованих ІКТ для підтримки взаємодії суб'єктів освітнього процесу. Ці технології використовуються для забезпечення необхідними навчально-методичними матеріалами (зокрема відкритими навчальними ресурсами); аналітичними даними навчання кожного студента; зворотним зв'язком між викладачем і студентами; навчання у соціальних мережах, форумах тощо. 
6. Створення єдиного ВНС. ВНС стало невід'ємною частиною електронної інфраструктури усіх університетів ДО. ВНС містить загальний інструментарій для створення контенту, комунікації, формального оцінювання та адміністрування. Більшість сучасних ВНС відкриті для інтеграції соціальних засобів масової інфрормації, таких як вікі та блоги.

7. Персоналізація навчання студентів за допомогою створення особистого навчального середовища. ОНС містить різний інструментарій, яким студент користується для навчання у повсякденному житті. ОНС створюється для підтримки навчально-пізнавальної діяльності, яка триває, не обмежуючись лише одним контекстом, єдиним провайдером, конкретним педагогічним підходом та формальною організацією. Структура ОНС залежить від наявних цифрових технологій, технологічних уподобань студента тощо.

\section{Бібліографрічні посилання}

[1] A law providing for the establishment and operation of the Open university of Cyprus. (2002). URL: https://rio.jrc.ec.europa.eu/en/library/law-234i2002-establishment-and-operation-open-university-cyprus.

[2] Downes, S. (2006). Models for sustainable open educational resources. URL: http://www.oecd.org/education/ceri/36781698.pdf.

[3] EADTU - European Association of Distance Teaching Universities. (2017). URL: https://www.distancelearningportal.com/partners/eadtu/.

[4] Hermans, H., Janssen, J., Vogten, H., \& Koper, R. (2015). Flexible provisioning adult learners. Journal of universal computer science, 21(2), 206-222.

[5] Hermans, H., Kalz, M., \& Koper, R. (2014). Toward a learner-centred system for adult learning. Campus-wide information systems, 31(1), 2-13.

[6] International Telematic University. (2016). URL: https://www.uninettunouniversity.net/en/default.aspx.

[7] Kim, A. J. (2000). Community Building on the Web: Secret strategies for successful online communities. Peachpit Press: Berkeley.

[8] Koper, R. (2009). A Conceptual Model of Learning Networks. In Koper, R., \& Tattersall, C. (Eds.), Learning Network Services for Professional Development (pp. 313-328). Berlin: Springer Heidelberg.

[9] Lane, A. (2006). From Pillar to Post: Exploring the issues involved in re-purposing distance learning materials for use as open educational resources. URL: http://kn.open.ac.uk/public/document.cfm?docid=9724

[10] McAndrew, P., \& Hirst, T. (2007). Open content for open development. The second Ten Competence workshop on Service Oriented Approaches and Lifelong Competence Development Infrastructures, Manchester, 11-12 January. URL: http://kn.open.ac.uk/document.cfm?docid=9127.

[11] Moore, M., \& Tait, A. (2002). Open and distance learning.trends, policy and strategy considerations. UNESCO, 23(2), 96. URL: http://unesdoc.unesco.org/images/0012/001284/128463e.pdf

[12] Owusu-Boampong, A., \& Holmberg, C. (2015). Distance education in European higher education: Report 3 (of 3) of the IDEAL. Oslo: International Council for Open and Distance Education.

[13] Pereira, A., Mendes, A. Q., Morgado, L., Amante, L., \& Bidarra, A. (2007). Universidade Aberta's Pedagogical Model for Distance Education: A University for the Future. Lisboa: Universidade Aberta.

[14] Pulker, H. (2016). The response to current challenges from an institution of open and distance learning. URL: https://journals.openedition.org/dms/1527

[15] Schneller, Ch., \& Holmberg, C. (2013). Distance Education in European Higher Education - the Offer: Report of the IDEAL. Oslo: International Council for Open and Distance Education.

[16] Schneller, Ch., \& Holmberg, C. (2014). Distance Education in European Higher Education - the Students: Report of the IDEAL. Oslo: International Council for Open and Distance Education

[17] Smith, M. S., \& Casserly, C. M. (2006). The promise of open educational resources. Change 38(5), 8-17.

[18] Sursock, A., \& Smidt, H. (2010). Trends 2010: A decade of change in European Higher Education. URL: http://www.eua.be/Libraries/higher-education/trends2010.pdf?sfvrsn=0.

[19] Taylor, J. C. (2013) Learning Journeys: the road from informal to formal learning. Journal of Interactive Media in Education (JIME), 2, 8.

[20] Verjans, S. (2014). Open University of The Netherlands: Educational models, virtual learning environments and support for e-learning. URL: http://dspace.ou.n//handle/1820/5852.

\section{References}

[1] A law providing for the establishment and operation of the Open university of Cyprus. (2002). URL: https://rio.jrc.ec.europa.eu/en/library/law-234i2002-establishment-and-operation-open-university-cyprus.

[2] Downes, S. (2006). Models for sustainable open educational resources. URL: http://www.oecd.org/education/ceri/36781698.pdf. 


[3] EADTU - European Association of Distance Teaching Universities. (2017). URL:
https://www.distancelearningportal.com/partners/eadtul.

[4] Hermans, H., Janssen, J., Vogten, H., \& Koper, R. (2015). Flexible provisioning adult learners. Journal of universal computer science, 21(2), 206-222.

[5] Hermans, H., Kalz, M., \& Koper, R. (2014). Toward a learner-centred system for adult learning. Campus-wide information systems, 31(1), 2-13.

[6] International Telematic University. (2016). URL: https://www.uninettunouniversity.net/en/default.aspx.

[7] Kim, A. J. (2000). Community Building on the Web: Secret strategies for successful online communities. Peachpit Press: Berkeley.

[8] Koper, R. (2009). A Conceptual Model of Learning Networks. In Koper, R., \& Tattersall, C. (Eds.), Learning Network Services for Professional Development (pp. 313-328). Berlin: Springer Heidelberg.

[9] Lane, A. (2006). From Pillar to Post: Exploring the issues involved in re-purposing distance learning materials for use as open educational resources. URL: http://kn.open.ac.uk/public/document.cfm?docid=9724

[10] McAndrew, P., \& Hirst, T. (2007). Open content for open development. The second Ten Competence workshop on Service Oriented Approaches and Lifelong Competence Development Infrastructures, Manchester, 11-12 January. URL: http://kn.open.ac.uk/document.cfm?docid=9127.

[11] Moore, M., \& Tait, A. (2002). Open and distance learning.trends, policy and strategy considerations. UNESCO, 23(2), 96. URL: http://unesdoc.unesco.org/images/0012/001284/128463e.pdf

[12] Owusu-Boampong, A., \& Holmberg, C. (2015). Distance education in European higher education: Report 3 (of 3) of the IDEAL. Oslo: International Council for Open and Distance Education.

[13] Pereira, A., Mendes, A. Q., Morgado, L., Amante, L., \& Bidarra, A. (2007). Universidade Aberta's Pedagogical Model for Distance Education: A University for the Future. Lisboa: Universidade Aberta.

[14] Pulker, H. (2016). The response to current challenges from an institution of open and distance learning. URL: https://journals. openedition.org/dms/1527

[15] Schneller, Ch., \& Holmberg, C. (2013). Distance Education in European Higher Education - the Offer: Report of the IDEAL. Oslo: International Council for Open and Distance Education.

[16] Schneller, Ch., \& Holmberg, C. (2014). Distance Education in European Higher Education - the Students: Report of the IDEAL. Oslo: International Council for Open and Distance Education

[17] Smith, M. S., \& Casserly, C. M. (2006). The promise of open educational resources. Change 38(5), 8-17.

[18] Sursock, A., \& Smidt, H. (2010). Trends 2010: A decade of change in European Higher Education. URL: http://www.eua.be/Libraries/higher-education/trends2010.pdf?sfvrsn=0.

[19] Taylor, J. C. (2013) Learning Journeys: the road from informal to formal learning. Journal of Interactive Media in Education (JIME), $2,8$.

[20] Verjans, S. (2014). Open University of The Netherlands: Educational models, virtual learning environments and support for e-learning. URL: http://dspace.ou.n//handle/1820/5852.

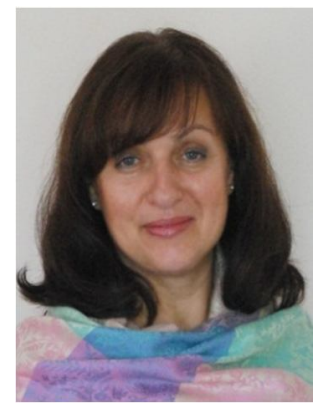

\section{Дернова Майя Григорівна.}

к.пед.н, доцент,

Кременчуцький національний університет імені Михайла Остроградського,

вул. Першотравнева, 20, 39600 м. Кременчук, Полтавська обл.

Тел. 0679516990. E-mail: maya.dernova@ukr.net

Dernova Maiia Grygorivna.

Ph.D (Pedagogy), Associate Professor,

Kremenchuk Mykhailo Ostrohradskyi National University, 20,

vul. Pershotravneva, Kremenchuk, Poltava region, Ukraine, 39600.

Tel. 0679516990. E-mail: maya.dernova@ukr.net

ORCID: 0000-0003-4545-5247

Researcher ID: I-8556-2018

Scopus ID: 57202585768

\section{Citation (APA):}

Dernova M. (2019). European Universities Experience in Distance Education. Engineering and Educational Technologies, 7 (2), $114-$ 125. doi: https://doi.org/10.30929/2307-9770.2019.07.02.12

\section{Цитування (ДСТУ 8302:2015):}

Дернова М. Г. Досвід європейських університетів в організації дистанційної освіти / Інженерні та освітні технології. 2019. Т. 7. № 2. C. 114-125. doi: https://doi.org/10.30929/2307-9770.2019.07.02.12

Обсяг статmі: сторінок - 12; умовних друк. аркушів - 1,738. 